DOI 10.14746/ssp.2018.1.5

Małgorzata ADAMIK-SZYSIAK

Uniwersytet Marii Curie-Skłodowskiej w Lublinie

\title{
Kampania wyborcza do Parlamentu Europejskiego w 2014 roku na lamach prasy ogólnopolskiej - studium przypadku „Gazety Wyborczej” i ,Rzeczpospolitej”
}

Streszczenie: $\mathrm{W}$ artykule podjęto próbę ukazania agendy dwóch dzienników ogólnopolskich „Gazety Wyborczej” i „Rzeczpospolitej”, związanej z nagłośnieniem kampanii wyborczej poprzedzającej wybory do Parlamentu Europejskiego w 2014 roku. Przedmiotem badań empirycznych uczyniono zarówno obecność na łamach wspomnianej prasy problematyki dotyczącej poszczególnych ugrupowań politycznych, jak i sposób jej prezentacji opinii publicznej. Jednym z rezultatów przeprowadzonej analizy jest pozytywnie zweryfikowana hipoteza wskazująca na wysoki stopień współzależności rankingu tematów agendy medialnej i publicznej w badanym okresie (współczynnik Pearsona wyniósł 0,93).

Słowa kluczowe: kampania wyborcza, Parlament Europejski, „Gazeta Wyborcza”, „Rzeczpospolita”, analiza zawartości

\section{Wprowadzenie}

Wybory do Parlamentu Europejskiego w 2014 roku były trzecimi z kolei wyborami od momentu wejścia Polski do Unii Europejskiej. Dotychczasowa niska frekwencja wyborcza (sięgająca nieco powyżej $20 \%{ }^{1}$ ) dowodzi, iż wybory te postrzegane są przez polskie społeczeństwo jako najmniej znaczące spośród wszystkich bezpośrednich wyborów przeprowadzanych zarówno na szczeblu krajowym, jak i samorządowym, co nie ma jednak przełożenia na stopień poparcia Polaków do idei integracji (zob.: Roguska, 2014; Pankowski, 2014). Z prowadzonych cyklicznie przez Centrum Badania Opinii Społecznej (CBOS) badań wynika, iż

${ }^{1}$ Frekwencja wyborcza w Polsce w dotychczasowych wyborach do Parlamentu Europejskiego wynosiła: w 2004 r. - 20,87\%, w 2009 r. -24,53\%, natomiast w 2014 r. $-23,83 \%$ (PKW, 2014a). 
mimo upływu 10 lat członkowstwa Polski w Unii Europejskiej, wybory do Parlamentu Europejskiego nadal w niewielkim stopniu interesują Polaków. Wśród przyczyn absencji wyborczej ankietowani wskazują m.in. brak zauważalnego wpływu wspomnianych wyborów na życie obywateli czy ograniczone zaufanie do klasy politycznej, dla której istotniejsze od interesów państwowych jest zaspakajanie własnych aspiracji, zwłaszcza finansowych (zob.: Badora, 2014; Adamik-Szysiak, 2014, s. 157-178).

W rezultacie wyborów, które odbyły się 25 maja 2014 roku mandaty w Parlamencie Europejskim uzyskało pięć polskich ugrupowań politycznych (tab. 1): Platforma Obywatelska (PO), Prawo i Sprawiedliwość (PiS), koalicja Sojuszu Lewicy Demokratycznej i Unii Pracy (SLD-UP), Polskie Stronnictwo Ludowe (PSL) oraz Nowa Prawica - Janusza Korwin-Mikke (NP-JKM). Dużym zaskoczeniem był w tych wyborach ostateczny stopień poparcia uzyskany przez NP-JKM (zob. Cybulska, 2014), której założyciel i lider Janusz Korwin-Mikke, od kilkunastu lat systematycznie prowadził nieefektywne kampanie w wyborach na poziomie ogólnopolskim (w tym ubiegając się również o urząd Prezydenta RP), co więcej jest zagorzałym przeciwnikiem Unii Europejskiej (zob. Strona, $2014)^{2}$.

Tabela 1

Wyniki wyborów do Parlamentu Europejskiego w Polsce w 2014 r.

\begin{tabular}{|l|c|c||}
\hline \multicolumn{1}{|c|}{ Nazwa podmiotu } & $\begin{array}{c}\text { Uzyskane poparcie } \\
\text { w skali kraju [\%] }\end{array}$ & $\begin{array}{c}\text { Liczba } \\
\text { mandatów }\end{array}$ \\
\hline \multicolumn{1}{|c|}{1} & 2 & 3 \\
\hline Platforma Obywatelska (PO) & 32,13 & 19 \\
\hline Prawo i Sprawiedliwość (PiS) & 31,78 & 19 \\
\hline Europa Plus Twój Ruch (EP TR) & 3,57 & 0 \\
\hline Sojusz Lewicy Demokratycznej - Unia Pracy (SLD-UP) & 9,44 & 5 \\
\hline Polskie Stronnictwo Ludowe (PSL) & 6,80 & 4 \\
\hline
\end{tabular}

${ }^{2}$ Zwolennicy Janusza Kowina-Mikke nie mieli do tej pory swej reprezentacji w Parlamencie Europejskim, a w przeprowadzonym przez CBOS tuż przed wyborami sondażu ugrupowanie NP-JKM zanotowało $4 \%$ poparcia. Swe stanowisko do Unii Europejskiej Janusz Kowin-Mikke podkreślał chociażby już w winiecie własnej strony internetowej, na której wyeksponowane były (zmieniające się) kolejne fragmenty wypowiedzi polityka dotyczące różnych sfer życia politycznego i społecznego, w tym integracji europejskiej, np. „Jestem za wejściem do strefy wolnego handlu! Tylko, że UE nie jest taką strefa, a strefą szalejącej biurokracji...”, „Jeśli mamy wychodzić z naszego zaścianka, to po co wchodzić do Eurozadupia? Lepiej dołączyć się do krajów gdzie panuje wolność...” czy „Eurosocjalizm jest co prawda lepszy od socjalizmu sowieckiego, bo już nie morduja, tylko kradną. Ale nadal jest to system zły...". 


\begin{tabular}{||l|l|l||}
\hline \multicolumn{1}{|c|}{1} & 2 & 3 \\
\hline Nowa Prawica - Janusza Korwin-Mikke (NP-JKM) & 7,15 & 4 \\
\hline Solidarna Polska Zbigniewa Ziobro (SP) & 3,98 & 0 \\
\hline Polska Razem Jarosława Gowina (PR) & 3,16 & 0 \\
\hline Ruch Narodowy (RN) & 1,39 & 0 \\
\hline Demokracja Bezpośrednia & 0,23 & 0 \\
\hline Samoobrona & 0,04 & 0 \\
\hline Partia Zieloni & 0,32 & 0 \\
\hline
\end{tabular}

Źródło: PKW (PKW, 2014b).

Celem artykułu jest próba ukazania proporcji nagłośnienia medialnego kampanii poprzedzającej trzecie z kolei w Polsce wybory do Parlamentu Europejskiego w perspektywie przeprowadzonych badań empirycznych w zakresie analizy zawartości „Gazety Wyborczej” i „Rzeczpospolitej”. Postawione pytania badawcze dotyczą poziomu korelacji dziennikarstwa i polityki w okresie wspomnianej kampanii wyborczej. W badaniu postawiono trzy hipotezy badawcze. Wedle pierwszej hipotezy, ilość i jakość materiałów traktujących o kampanii wyborczej w 2014 roku zamieszczanych na łamach dzienników opiniotwórczych dowodzi faworyzowania wybranych podmiotów politycznych w rezultacie cieszących się największym poparciem społecznym. Druga hipoteza stanowi, iż w materiałach dziennikarskich wyraźne zauważalne jest zjawisko personalizacji polityki, ukazanej jednak głównie przez pryzmat działalności liderów ugrupowań politycznych i/lub kandydatów zajmujących czołowe miejsca na listach wyborczych, szansą na zaistnienie w mediach pozostałych kandydatów jest podejmowanie oryginalnych, często kontrowersyjnych działań w ramach kampanii wyborczej. Trzecia hipoteza wskazuje, iż podmioty polityczne prezentowane są na łamach dzienników opiniotwórczych nie tylko w kontekście prowadzonej kampanii wyborczej, ale także wybranych postulatów programowych.

Posługując się metodą analizy zawartości, zarówno ilościowej, jak i jakościowej, a także posiłkując się teorią agenda-setting (McCombs, 2008, s. 182), badaniu poddano wszystkie materiały dotyczące kampanii wyborczej do Parlamentu Europejskiego opublikowane na łamach dwóch dzienników ogólnopolskich: „Gazety Wyborczej” (GW) i „Rzeczpospolitej” (Rz) w okresie od 19 lutego 2014 roku (dzień ogłoszenia przez Prezydenta RP terminu wyborów (Postanowienie, 2014), a więc moment rozpoczęcia oficjalnej kampanii wyborczej) do 23 maja 2014 roku (ostatni dzień kampanii wyborczej). Łącznie przeanalizowano 479 różnorodnych 
tekstowych oraz 260 materiałów ilustracyjnych. Za podstawowe kryteria wyboru tytułów prasowych uznano wysokość sprzedaży oraz poziom czytelnictwa poważnych ${ }^{3}$ dzienników opiniotwórczych w Polsce (zob. ZKDP, 2014).

W rezultacie przeanalizowano materiały stanowiące szeroki zakres gatunkowy (wykres 1) dotyczące biorących udział w kampanii ugrupowań politycznych i ich reprezentantów, a także wykładni obowiązującego prawa wyborczego, w tym działań informacyjnych rozpowszechnianych przez Państwową Komisję Wyborczą. Przedmiotem zainteresowania uczyniono nie tylko materiały tekstowe, ale również ilustracyjne/graficzne, w tym zdjęcia, wykresy, diagramy.

\section{Wyniki badań}

Ilościowa analiza zebranego materiału wykazała, iż kampania wyborcza poprzedzająca wybory do Parlamentu Europejskiego w 2014 roku w nieco większym stopniu opisywana była w „Rzeczpospolitej”. Na łamach „Gazety Wyborczej” do badania wyłoniono łącznie 209 materiałów tekstowych oraz 127 materiałów ilustracyjnych/graficznych, natomiast w „Rzeczpospolitej” - 270 materiałów tekstowych oraz 133 materiałów ilustracyjnych/graficznych.

W „Gazecie Wyborczej” dziennikarze, opisując kampanię wyborczą, najczęściej wykorzystywali informację (30\% wszystkich materiałów) oraz artykuł (20\%, wykres 1$)$, w obu przypadkach niemal stałym elementem materiałów były zdjęcia (głównie fotografie sytuacyjne i tzw. „główki”). Z kolei w „Rzeczpospolitej” czytelnik mógł odnaleźć więcej tematycznych artykułów (29\% wszystkich materiałów) i nieco mniej informacji (25\%), podobnie jak w „Gazecie Wyborczej” zazwyczaj dopełnionych adekwatnym, raczej neutralnym zdjęciem sytuacyjnym lub tzw. „główką”. Leady informacji z reguły w obu gazetach pełniły przede wszystkim funkcję informacyjną, nieliczne odstępstwa od tej zasady pojawiały się częściej na łamach „Rzeczpospolitej” (np. Olczyk, Grabek, 2014, s. A3) .

W identycznym stopniu (po 15\%) dzienniki czerpały ze wzmianki/notatki (wykres 1). Niemal dwukrotnie więcej niż w „Rzeczpospolitej” (8\%)

3 Ze względu na odmienny (od przywołanych tu dzienników) charakter z badań wyłączono plasujące się od kilku lat w Polsce w czołówce rankingów sprzedaży tabloidy.

${ }^{4} \mathrm{~Np}$. Lead: „Liczą na thustą emeryturę, muszą zniknąć z oczu opinii publicznej lub po prostu chcą więcej czasu spędzać z rodziną w Brukseli”. 
na łamach „Gazety Wyborczej” opublikowano komentarzy (14\%). Warto przy tym dodać, iż komentatorami w „Gazecie Wyborczej” byli często politycy aktualnie niesprawujący funkcji na polskiej scenie politycznej, jak Henryka Bochniarz czy Aleksander Kwaśniewski (zob. Bochniarz, 2014, s. 8; Grochal, 2014a, s. 8-9). Poza publikowaniem w obu gazetach sondaży przedwyborczych przeprowadzonych przez ośrodki badania opinii publicznej, zauważyć należy, iż oba dzienniki opracowały również własne rankingi dotyczące aktywności polskich europosłów mijającej kadencji. „Sędziami” w rankingu „Rzeczpospolitej” byli reprezentanci różnych mediów (zob. Słojewska, 2014, s. A4-A5), natomiast w „Gazecie Wyborczej” wyłącznie dziennikarze dziennika - autorzy materiału (zob. Bielecki, Grochal, Kondzińska, 2014, s. 10-11). Porównując oba materiały zauważyć należy, iż bardziej stronnicza w sposobie prezentacji (zarówno na poziomie jakości przytoczonych argumentów, jak i sformułowań językowych), okazała się „Gazeta Wyborcza”, w której jednoznacznie pozytywnie oceniono europosłów z ramienia PO oraz SLD, negatywnie - PiS.

Podkreślenia wymaga fakt, iż tylko w „Gazecie Wyborczej” odwołano się do gatunku, jakim jest sylwetka - w taki sposób zaprezentowano jednak głównie wybranych kandydatów (np. Kondzińska, 2014a, s. 10-11) Ruchu Narodowego, w tym jego lidera Mariana Kowalskiego (zob. Adamaszek, Reszka, 2014, s. 8).

Więcej wywiadów opublikowanych zostało na łamach „Rzeczpospolitej” (5\% wszystkich materiałów), dziennik ten zamieszczał również obszerniejsze w porównaniu do „Gazety Wyborczej” (jedno - a nawet dwustronicowe) materiały, niejednokrotnie opatrzone (niekiedy również całostronicowymi) zdjęciami portretowymi ich bohaterów. Oba dzienniki najczęściej prezentowały polityków dwóch partii cieszących się największym poparciem społecznym w sondażowych badaniach przedwyborczych: Platformy Obywatelskiej oraz Prawa i Sprawiedliwości (zob. Cybulska, 2014) ${ }^{6}$. Wywiady na łamach obu dzienników dotyczyły przede

5 Np. Łukasza Kluski, jednego z kandydatów Ruchu Narodowego, jak podkreślano nawet w szeregach samego ugrupowania, o ,wyjątkowo" radykalnych poglądach (polityk opowiadał się m.in. za wprowadzeniem zakazu rozwodów czy cenzury obyczajowej); o wspomnianym kandydacie pisano również na łamach „Rzeczpospolitej”, w tym jednak przypadku przez pryzmat zawartości jego spotu wyborczego (Olczyk, 2014a, s. 10-11).

${ }^{6} \mathrm{~W}$ badaniach sondażowych prowadzonych przez CBOS od marca do maja 2014 r. poparcie dla Platformy Obywatelskiej wynosiło 21-19\%, natomiast dla Prawa i Sprawiedliwości - 21-22\%. 
Wykres 1. Rodzaje przeanalizowanych materiałów na lamach dzienników

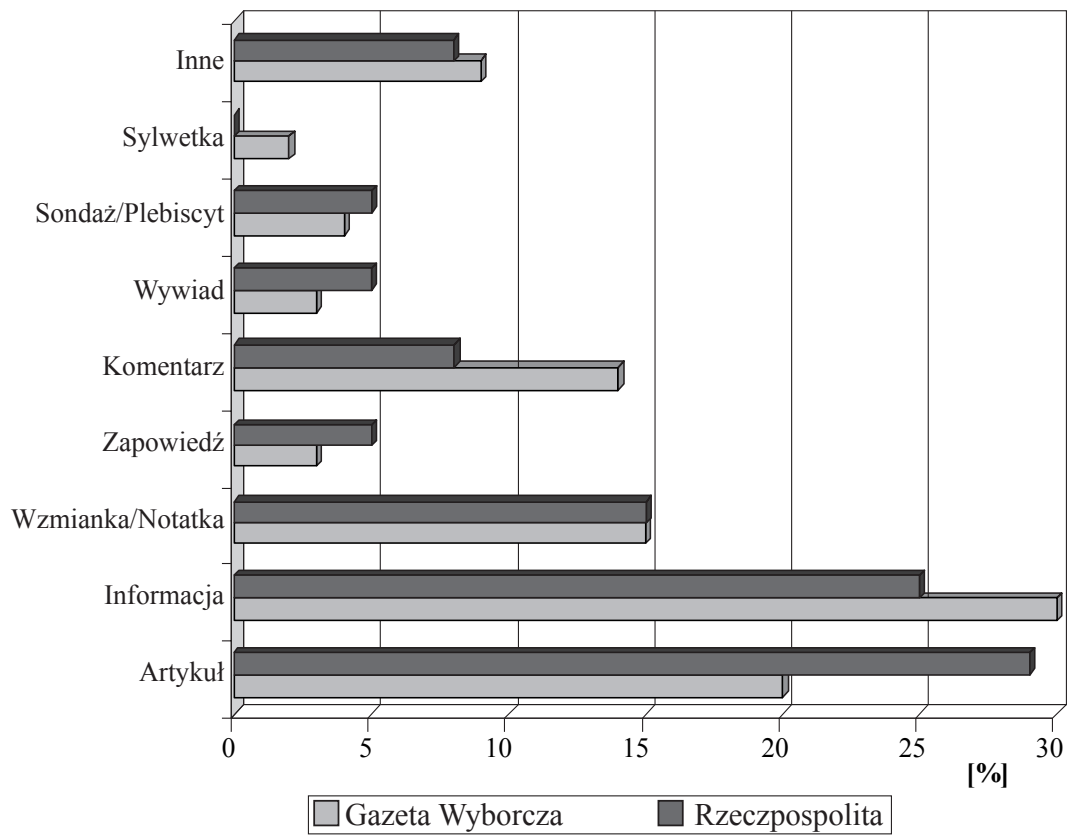

Źródło: Opracowanie własne.

wszystkim działań prowadzonych w ramach kampanii wyborczej, prognoz na sukces wyborczy, wybranych postulatów programowych oraz zajmowanego stanowiska wobec aktualnych wydarzeń politycznych (np. Nizinkiewicz, 2014a, s. A6; Nizinkiewicz, 2014b, s. A9; Grochal, 2014b, s. 10-11). Uwagę czytelnika, ze względu na obszerność (dwie strony, poprzedzone zapowiedzią na czołówce gazety), zwracał opublikowany jedynie na łamach „Rzeczpospolitej” końcem marca wywiad z niekandydującym w wyborach do europarlamentu liderem PiS Jarosławem Kaczyńskim (zob. Majewski, Szułdrzyński, 2014, s. A6-A7).

Zauważalne, iż oba dzienniki opublikowały wywiady z reprezentantami dwóch mniejszych ugrupowań, którym sondaże przedwyborcze dawały niewielkie szanse na sukces wyborczy, Solidarnej Polski Zbigniewa Ziobro oraz Polski Razem Jarosława Gowina (zob. Cybulska, 2014) ${ }^{7}$, co

7 W badaniach CBOS poparcie dla Polski Razem Jarosława Gowina oscylowało w granicach 2-4\%, natomiast dla Solidarnej Polski Zbigniewa Ziobro 1-2\%. 
więcej na łamach „Rzeczpospolitej” wywiady te zamieszczono w sąsiadujących kolumnach (Nizinkiewicz, 2014c, s. A5; Nizinkiewicz, 2014d, s. A5). „Rzeczpospolita” dodatkowo zaprezentowała wywiad z kandydatem koalicji Europa Plus Twój Ruch Ryszardem Kaliszem (Stankiewicz, 2014, s. A5), a także obszerny (opatrzony całostronicowym zdjęciem polityka) wywiad z Januszem Korwinem-Mikke, liderem i zarazem kandydatem ugrupowania Nowa Prawica - Janusza Korwina-Mikke (Cybulska, 2014; Mazurek, 2014, s. P10-11).

Z kolei na łamach „Gazety Wyborczej” zamieszczono wywiady z szefami sztabów wyborczych, najwięcej miejsca poświęcając jednak koordynującemu kampanię PSL Adamowi Jarubasowi (Kędracki, 2014, s. $12-13)^{9}$.

Uwagę obu dzienników, co uwypuklone zostało w formie wywiadu z politykiem, zwrócił również „polityczny transfer” wieloletniego działacza PiS Michała Kamińskiego do konkurencyjnej partii - PO (Nowakowska, 2014a, s. 5; Nizinkiewicz, 2014e, s. A5).

Wśród materiałów zakwalifikowanych do kategorii „inne” na podkreślenie zasługuje zamieszczone w „Rzeczpospolitej” swoiste podsumowanie przebiegu całej kampanii w formie przejrzystego alfabetu minionych wydarzeń (Olczyk, 2014b, s. A6).

Badanie zgromadzonych materiałów ilustracyjnych na łamach obu dzienników wykazało ilościową dysproporcję między reprezentantami dwóch największych na polskiej scenie politycznej partii: współrządząca z PSL Platformą Obywatelską oraz najliczniejszą opozycyjną - Prawem i Sprawiedliwością a liderami i/lub kandydatami pozostałych ugrupowań (tab. 2 i 3). Zarówno na łamach „Gazety Wyborczej”, jak i „Rzeczpospolitej" polityków (liderów i/lub kandydatów) PO oraz PiS prezentowano, posługując się tzw. „główką" lub zdjęciem sytuacyjnym (np. z konferencji prasowych czy spotkań z wyborcami). Zdjęcia billboardów, plakatów lub kadrów ze spotów wyborczych w obu dziennikach zamieszczano przy tematycznych materiałach tekstowych opisujących zdaniem dziennikarzy medialne/kontrowersyjne działania promocyjne kandydatów i/lub par-

8 Poparcie sondażowe dla koalicji Europa Plus Twój Ruch przed wyborami wynosiło 2-3\%, natomiast dla Nowej Prawicy - Janusza Korwina-Mikke 4-6\%.

9 PSL w sondażach przedwyborczych również nie cieszyło się zbyt dużym poparciem społecznym oscylującym w granicach 3-6\%, warto jednak dodać, iż wspomniany Adam Jarubas z końcem stycznia 2016 r. został oficjalnie zgłoszony jako kandydat tej partii w wyborach prezydenckich, zdobywając ostatecznie 1,6\% głosów (Cybulska, 2014; PKW, 2015). 
tii. Warto tu jednak zwrócić uwagę, iż w przypadku PO oraz PiS uwagę redakcji obu gazet zwracały podobne promocyjne materiały wyborcze rozpowszechniane przez podmioty polityczne, inaczej jednak było w odniesieniu do działalności pozostałych ugrupowań. „Gazetę Wyborczą" zainteresowały materiały promocyjne Solidarnej Polski Zbigniewa Ziobro oraz Ruchu Narodowego, natomiast „Rzeczpospolita” - koalicji Europa Plus Twój Ruch oraz Polski Razem Jarosława Gowina (tab. 2 i 3 ) Dodać należy, iż materiały ilustracyjne w obu gazetach miały charakter neutralny, pełniąc tym samym funkcję informacyjną.

Tabela 2

Wizerunki polityków poszczególnych ugrupowań politycznych na lamach „Gazety Wyborczej” [\%]

\begin{tabular}{|c|c|c|c|c|c|c|c|c|c|}
\hline \multirow{2}{*}{$\begin{array}{l}\text { Rodzaj materiału } \\
\text { wizualnego }\end{array}$} & \multicolumn{9}{|c|}{ Gazeta Wyborcza [\%] } \\
\hline & PO & PiS & EP TR & SLD-UP & PSL & $\begin{array}{c}\text { NP } \\
\text { JKM }\end{array}$ & SP & PR & $\mathbf{R N}$ \\
\hline Zdjęcie sytuacyjne & 38 & 32 & 5 & 17 & 5 & 0 & 3 & 0 & 0 \\
\hline Główka/portret & 35 & 26 & 5 & 7 & 6 & 3 & 5 & 6 & 3 \\
\hline $\begin{array}{l}\text { Plakat/billboard/kadr } \\
\text { ze spotu }\end{array}$ & 25 & 25 & 0 & 0 & 0 & 0 & 25 & 0 & 25 \\
\hline $\begin{array}{l}\text { Łączna ilość materiału } \\
\text { wizualnego poświęco- } \\
\text { nego danemu ugrupo- } \\
\text { waniu }[\%]\end{array}$ & 37 & 25 & 7 & 10 & 5 & 2 & 7 & 5 & 2 \\
\hline
\end{tabular}

Źródło: Opracowanie własne.

Tabela 3

Wizerunki polityków poszczególnych ugrupowań politycznych na lamach „Rzeczpospolitej” [\%]

\begin{tabular}{|c|c|c|c|c|c|c|c|c|c|}
\hline \multirow[b]{2}{*}{$\begin{array}{l}\text { Rodzaj materiału } \\
\text { wizualnego }\end{array}$} & \multicolumn{9}{|c|}{ Rzeczpospolita [\%] } \\
\hline & PO & PiS & EP TR & SLD-UP & PSL & \begin{tabular}{|c|} 
NP \\
JKM
\end{tabular} & SP & PR & $\mathbf{R N}$ \\
\hline Zdjęcie sytuacyjne & 37 & 14 & 9 & 23 & 6 & 4 & 4 & 2 & 1 \\
\hline Główka/portret & 41 & 21 & 4 & 8 & 6 & 6 & 6 & 6 & 2 \\
\hline $\begin{array}{l}\text { Plakat/billboard/kadr ze } \\
\text { spotu }\end{array}$ & 20 & 30 & 30 & 0 & 0 & 0 & 0 & 20 & 0 \\
\hline $\begin{array}{l}\text { Łączna ilość materiału } \\
\text { wizualnego poświęco- } \\
\text { nego danemu ugrupo- } \\
\text { waniu [\%] }\end{array}$ & 38 & 21 & 8 & 13 & 5 & 4 & 4 & 5 & 2 \\
\hline
\end{tabular}

Źródło: Opracowanie własne. 
Analiza materiału badawczego pod kątem dominacji określonej problematyki pozwoliła wyróżnić dziesięć kategorii treściowych: działalność kampanijna, program/obietnice wyborcze, pieniądze wydane na realizację kampanii, poparcie udzielone kandydatom, billboardy/spoty wyborcze/slogany, sondaże wyborcze, plebiscyty wyborcze, listy wyborcze, prawo wyborcze i inne (wykres 2).

\section{Wykres 2. Problematyka przeanalizowanych materiałów na lamach dzienników}

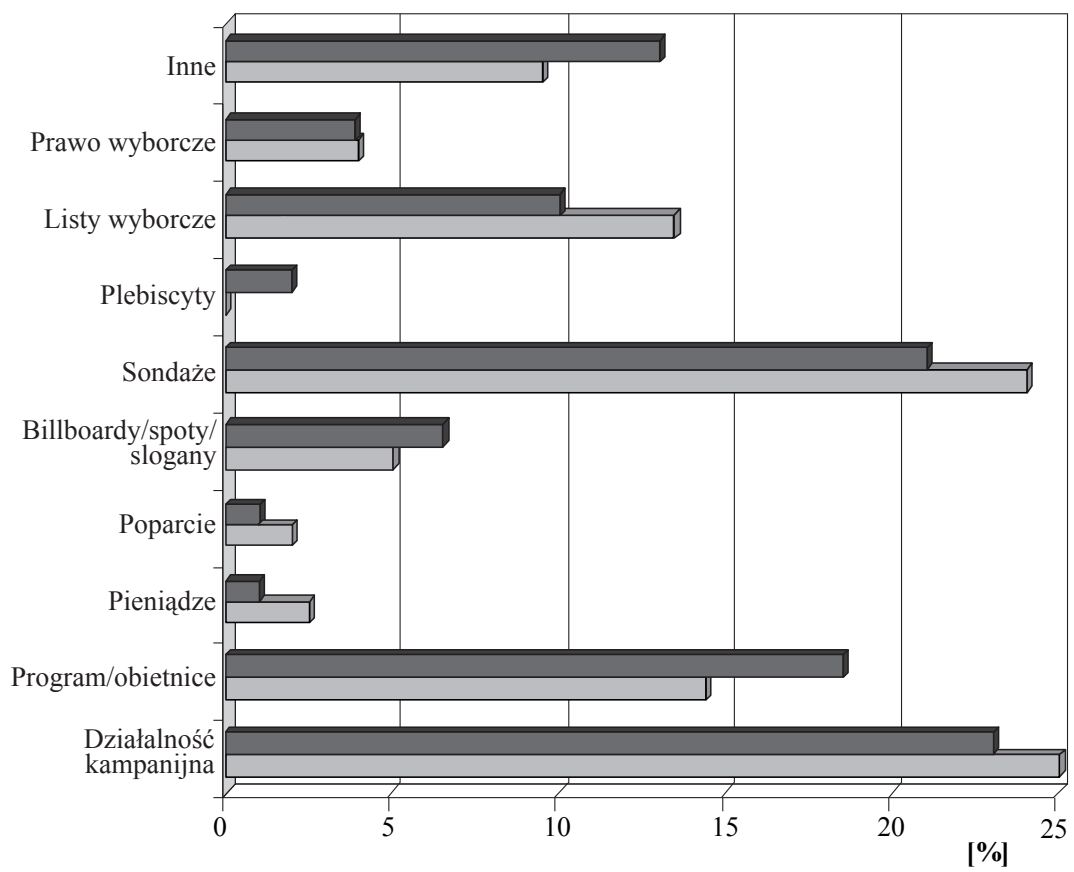

Źródło: Opracowanie własne.

Tabela 4

Problematyka opublikowanych na lamach dzienników materiałów dotyczących poszczególnych ugrupowań politycznych, cz. I [\%]

\begin{tabular}{|c|c|c|c|c|c|c|c|c|c|c|}
\hline \multirow[b]{2}{*}{ Kategoria } & \multicolumn{2}{|c|}{ PO } & \multicolumn{2}{|c|}{ PiS } & \multicolumn{2}{|c|}{ EP TR } & \multicolumn{2}{|c|}{ SLD-UP } & \multicolumn{2}{|c|}{ PSL } \\
\hline & GW & $\mathbf{R z}$ & GW & $\mathbf{R z}$ & GW & $\mathbf{R z}$ & GW & $\mathbf{R z}$ & GW & $\mathbf{R z}$ \\
\hline 1 & 2 & 3 & 4 & 5 & 6 & 7 & 8 & 9 & 10 & 11 \\
\hline Działalność $\rightarrow$ kampanijna & 24 & 24 & 29 & 19 & 7 & 10 & 13 & 13 & 7 & 8 \\
\hline
\end{tabular}




\begin{tabular}{||l|r|r|r|r|r|r|r|r|r|r||}
\hline \multicolumn{1}{|c|}{1} & 2 & 3 & 4 & 5 & 6 & 7 & 8 & 9 & 10 & 11 \\
\hline Program/obietnice & 17 & 15 & 23 & 14 & 10 & 13 & 11 & 16 & 10 & 11 \\
\hline Pieniądze & 25 & 50 & 34 & 16 & 8 & 0 & 25 & 16 & 8 & 16 \\
\hline Poparcie & 20 & 16 & 30 & 16 & 20 & 0 & 10 & 16 & 0 & 16 \\
\hline Billboardy/spoty/slogany & 0 & 17 & 35 & 26 & 17 & 17 & 4 & 8 & 9 & 3 \\
\hline Sondaże & 21 & 18 & 20 & 16 & 11 & 13 & 15 & 13 & 10 & 13 \\
\hline Plebiscyty & 0 & 23 & 0 & 23 & 0 & 8 & 0 & 8 & 0 & 8 \\
\hline Listy wyborcze & 28 & 20 & 25 & 23 & 9 & 2 & 5 & 9 & 8 & 7 \\
\hline Prawo wyborcze & 0 & 14 & 10 & 9 & 0 & 0 & 0 & 4 & 5 & 0 \\
\hline Inne & 18 & 26 & 12 & 18 & 7 & 8 & 9 & 14 & 3 & 7 \\
\hline
\end{tabular}

Źródło: Opracowanie własne.

Tabela 5

Problematyka opublikowanych na lamach dzienników materiałów dotyczących poszczególnych ugrupowań politycznych, cz. II [\%]

\begin{tabular}{||l|c|c|c|c|c|c|c|c||}
\hline \multirow{2}{*}{$\begin{array}{r}\text { Partia/ } \\
\text { Dziennik }\end{array}$} & NP-JKM & \multicolumn{2}{c|}{ SP } & \multicolumn{2}{c|}{ PR } & \multicolumn{2}{c|}{ RN } \\
\cline { 2 - 11 } Kategoria & GW & Rz & GW & Rz & GW & Rz & GW & Rz \\
\hline Działalność $\rightarrow$ kampanijna & 3 & 6 & 6 & 5 & 4 & 5 & 3 & 3 \\
\hline Program/obietnice & 10 & 8 & 9 & 8 & 6 & 7 & 4 & 5 \\
\hline Pieniądze & 0 & 0 & 0 & 0 & 0 & 0 & 0 & 0 \\
\hline Poparcie & 0 & 0 & 10 & 34 & 0 & 0 & 0 & 0 \\
\hline Billboardy/spoty/slogany & 0 & 6 & 0 & 6 & 9 & 14 & 4 & 0 \\
\hline Sondaże & 8 & 10 & 5 & 7 & 6 & 8 & 3 & 3 \\
\hline Plebiscyty & 0 & 0 & 0 & 8 & 0 & 15 & 0 & 8 \\
\hline Listy wyborcze & 5 & 5 & 10 & 13 & 6 & 5 & 0 & 2 \\
\hline Prawo wyborcze & 0 & 9 & 0 & 0 & 0 & 9 & 0 & 4 \\
\hline Inne & 3 & 4 & 9 & 6 & 5 & 6 & 9 & 3 \\
\hline \hline
\end{tabular}

Źródło: Opracowanie własne.

Kampania wyborcza na łamach obu dzienników ukazana została przede wszystkim przez pryzmat działalności kampanijnej liderów i/lub wybranych kandydatów ugrupowań politycznych („Gazeta Wyborcza” - 25\%, „Rzeczpospolita” - 23\% wszystkich materiałów prasowych) oraz sondaży wyborczych (,Gazeta Wyborcza” - 24\%, „Rzeczpospolita" - 21\% wszystkich materiałów prasowych). Zauważyć należy jednak, iż w obu wspomnianych kategoriach zarówno w „Gazecie Wyborczej”, jak i „Rzeczpospolitej” prym wiodły materiały informujące czytelników głównie o poczynaniach kandydatów PiS i PO oraz aktualnych ,słupkach poparcia" społecznego dla tych ugrupowań (tab. 4 i 5). W zbiorczych sondażach wyborczych „Gazeta Wyborcza” zazwyczaj uwypuklała pięć 
ugrupowań: PO, PiS, SLD-UP, EP TR oraz PSL, do wspomnianego grona „Rzeczpospolita” włączała również NP-JKM, pozostałe podmioty polityczne często przypisywane były do kategorii ,inne”. Podobnie było w przypadku opisu czy relacji z przebiegu kampanii wyborczej - tu oba dzienniki koncentrowały się głównie na poczynaniach PO i PiS, o których najczęściej pisano przez pryzmat działalności i wypowiedzi niekandydujących w wyborach liderów tych partii: Donalda Tuska i Jarosława Kaczyńskiego (np. Wielowieyska, Kursa, Szaro, 2014, s. 9; Majewski, 2014a, s. A5). Trafnym w tym kontekście wydaje się lead materiału opublikowanego na łamach „Rzeczpospolitej”: „Premier mobilizuje działaczy PO. Lider PiS zakończy kampanię na wschodzie kraju, uderzy w PSL i mniejsze partie" (Olczyk, Majewski, Pieńkowski, 2014, s. A3).

Zarówno „Gazetę Wyborczą”, jak i „Rzeczpospolitą” zajmowały także w mniejszym lub większym stopniu obietnice wyborcze składane przez reprezentantów wszystkich ugrupowań politycznych oraz (poza „Gazetą Wyborczą” w odniesieniu do Ruchu Narodowego) kształt list wyborczych (wykres 2, tab. 4 i 5). Dodatkowo „Rzeczpospolita” publikowała w kolejnych numerach wyniki ankiety (zawierającej „otwarte” pytania) przeprowadzonej wśród reprezentantów wszystkich ugrupowań politycznych dotyczącej istotnych zdaniem redakcji (w kontekście wyborów do europarlamentu) kwestii, w tym m.in. układu sił politycznych, gospodarki czy wolności sumienia (zob. Majewski, 2014b, s. A4; Majewski, 2014c, s. A6; Majewski, 2014d, s. A4; Majewski, 2014e, s. A8; Olczyk, 2014c, s. A4). Taki sposób prezentacji pozwolił redakcji na zachowanie względnej równowagi nie tylko pod względem przedstawienia zawartości merytorycznej programów wyborczych, ale również objętości, opublikowanych odpowiedzi polityków. Stronniczość dziennikarska podczas artykułowania postulatów wyborczych podmiotów politycznych znacznie częściej widoczna była już na etapie samych tytułów w materiałach zamieszczanych w „Gazecie Wyborczej” (np. Eurokoncert życzeń PiS, Wędzona kiełbasa wyborcza Kaczyńskiego czy Schizofrenia narodowców, zob. AJ, AGN, 2014, s. 5; Nowakowska, 2014b, s. 6; Kondzińska, 2014b, s. 5), dodać jednak należy, iż dziennik ten również w jednym z numerów zamieścił wyniki kwestionariusza, w którym liderzy wszystkich ugrupowań wypowiedzieli się na temat stosunku ich ugrupowania do wybranych kwestii, głównie gospodarczych, jednak tu pytania miały charakter ,zamknięty” i politycy mieli do ,wyboru” trzy możliwości odpowiedzi , tak”, ,nie”, ,nie mam opinii” (RED, 2014, s. 6-7). 
Kluczowa rola liderów ugrupowań politycznych była wyraźnie podkreślana przez dziennikarzy w materiałach poświęconych kształtowi list wyborczych. Nie tylko kandydujący ale i niekandydujący w tych wyborach liderzy, poza oficjalnym obdarzaniem kandydatów ugrupowania zaufaniem pełnili funkcje „lokomotyw wyborczych”. Warto dodać, iż na łamach „Gazety Wyborczej" na finiszu kampanii zamieszczano w kolejnych numerach specjalny dział: „Pojedynki pewniaków i partyjnych czarnych koni”, w którym czytelnik mógł znaleźć informacje o bieżącym poparciu i szansach na zwycięstwo tylko liderów list wyborczych głównych ugrupowań politycznych w różnych okręgach wyborczych (np. Wroński, 2014, s. 4). Oba dzienniki w największym stopniu interesowały się reprezentantami zajmującymi pierwsze miejsca na listach wyborczych w poszczególnych okręgach wyborczych dwóch największych partii, PO oraz PiS (tab. 4). Znamiennym przykładem może tu być jeden z materiałów opublikowanych na łamach „Gazety Wyborczej”, w którym wspominając o liderach list wyborczych poszczególnych ugrupowań w różnych regionach Polski zaprezentowano w warstwie wizualnej (wykorzystując tzw. „główki”) jedynie kandydatów PO i PiS, dodatkowo artykuł opatrzono zdjęciami z konwencji wyborczych wspomnianych partii, których głównymi bohaterami byli ich liderzy: Donald Tusk i Jarosław Kaczyński (zob. Grochal, Kondzińska, 2014, s. 4-5). O ile w „Rzeczpospolitej” ta personalizacja zauważalna była dopiero w treści materiałów, o tyle w „Gazecie Wyborczej” już na poziomie samych tytułów: Drużyna Tuska na eurowybory czy Europejska drużyna Kaczyńskiego (Grochal, 2014c, s. 3; Kondzińska, 2014c, s. 5). Warto dodać, iż w „Rzeczpospolitej” w kontekście tworzenia list wyborczych przez partie pisano również o „mechanizmach” marketingu wyborczego, jednak i tym razem przez pryzmat działań PiS oraz PO (np. Majewski, Pieńkowski, 2014, s. A6; Olczyk, 2014d, s. A7). Gazeta ta zwróciła również uwage na rywalizację byłych spin doktorów PiS, w tych wyborach ubiegających się o mandaty z konkurencyjnych ugrupowań: Michała Kamińskiego - PO, Adama Bielana - Polska Razem J. Gowina oraz Jacka Kurskiego - Solidarna Polska Z. Ziobro (zob. Majewski, 2014f, s. A3) ${ }^{10}$.

Ogólne zestawienie wskazuje, iż oba dzienniki w podobnym stopniu pisały o materiałach promocyjnych skonstruowanych przez kandydatów i/lub ugrupowania polityczne na potrzeby kampanii (zwłaszcza billboardach, spotach i sloganach wyborczych; w „Rzeczpospolitej” - 6,5\%,

${ }_{10}$ Warto dodać, iż żaden z wymienionych spin doktorów nie uzyskał ostatecznie mandatu. 
w „Gazecie Wyborczej” - 5\% wszystkich materiałów, wykres 2). Jednak szczegółowa analiza dowiodła, iż zbieżność ta dotyczyła jedynie kontrowersyjnych, medialnych, wpisujących się w kampanię negatywną działań realizowanych przez Europę Plus Twój Ruch (po 17\% wszystkich materiałów, tab. 4) - w opublikowanej w „Rzeczpospolitej” jednej z informacji zatytułowanej Pyskówki czas zaczqć, w leadzie dziennikarka wskazywała: „Europa Plus zainaugurowała swoją kampanię wyborczą spotem, w którym Janusz Palikot [lider koalicji - przyp. M. A.-Sz.] nazywa polityków PiS politycznymi knurami" (Olczyk, 2014e, s. A9). Duże zainteresowanie obu redakcji budziły billboardy i spoty wyborcze PiS, w przypadku „Rzeczpospolitej" również PO - co ciekawe, partii zupełnie zignorowanej pod tym względem na łamach „Gazety Wyborczej” (tab. 4).

\section{Konkluzje}

Wyniki uzyskanych danych z analizy materiałów tekstowych opublikowanych na łamach „Gazety Wyborczej” i „Rzeczpospolitej” w okresie trwania oficjalnej kampanii wyborczej do europarlamentu dowiodły, iż najwięcej uwagi dzienniki poświęciły ugrupowaniom politycznym, które w wyniku wyborów uzyskały najlepsze rezultaty: PO, PiS oraz koalicji SLD-UP (tab. 6). Materiały na temat kampanii wspomnianych trzech ugrupowań w „Gazecie Wyborczej” stanowiły 54\%, natomiast w „Rzeczpospolitej" - 50\% całości zgromadzonych źródeł.

Tabela 6

Ogółem \% materiałów tekstowych poświęconych podmiotom na lamach dzienników a uzyskane poparcie w wyborach

\begin{tabular}{|l|c|c|c|c|}
\hline $\begin{array}{l}\text { Nazwa Dziennik/ } \\
\text { podmiotu }\end{array}$ & $\begin{array}{c}\text { „Gazeta } \\
\text { Wyborcza" }\end{array}$ & $\begin{array}{c}\text { „Rzeczpos- } \\
\text { polita" }\end{array}$ & $\begin{array}{c}\text { Uzyskane poparcie } \\
\text { w skali kraju [\%] }\end{array}$ & $\begin{array}{c}\text { Liczba } \\
\text { mandatów }\end{array}$ \\
\hline PO & 20,0 & 20,0 & 32,13 & 19 \\
\hline PiS & 21,5 & 17,5 & 31,78 & 19 \\
\hline EP TR & 10,0 & 10,0 & 3,57 & 0 \\
\hline SLD-UP & 12,5 & 12,5 & 9,44 & 5 \\
\hline PSL & 8,0 & 6,5 & 6,80 & 4 \\
\hline NP-JKM & 4,0 & 7,0 & 7,15 & 4 \\
\hline SP & 6,0 & 7,0 & 3,98 & 0 \\
\hline PR & 5,0 & 7,0 & 3,16 & 0 \\
\hline RN & 3,0 & 3,0 & 1,39 & 0 \\
\hline \hline
\end{tabular}

Źródlo: Opracowanie własne. 
Badania materiałów wizualnych pod kątem dominacji wizerunków polityków ugrupowań politycznych na łamach dzienników doprowadziły do podobnych, jak w przypadku materiałów tekstowych, konstatacji. Najczęściej ukazywanymi politykami byli reprezentanci PO, PiS oraz SLD-UP (tab. 2 i 3). Sytuacja ta wynikała z publikowania materiałów tekstowych zazwyczaj opatrzonych adekwatnymi zdjęciami. W przypadku zamieszczanych materiałów wizualnych oba dzienniki starały się zachować neutralność polityczną, zachwianą jednak, zwłaszcza w przypadku „Gazety Wyborczej” w materiale tekstowym. Wspominana stronniczość „Gazety Wyborczej” zauważalna była przede wszystkim w kontekście prezentacji materiałów na temat $w$ znacznej mierze pozytywnie ocenianej kampanii PO oraz negatywnie - PiS.

Porównanie uzyskanych danych empirycznych dotyczących rankingu kwestii agendy medialnej z agendą publiczną (oficjalne wyniki wyborów PKW) daje postawy do potwierdzenia prawdziwości przyjętej hipotezy o wysokiej współzależności między rankingiem tematów agendy medialnej i publicznej - korelacja między zgromadzonymi danymi zachodzi na wysokim poziomie (współczynnik Pearsona wynosi 0,93), co sugeruje znaczny stopień oddziaływania agenda-setting (tab. 7). Można zatem wnioskować, iż stopień eksponowania informacji na temat poszczególnych ugrupowań politycznych mógł w znaczący sposób wpłynąć na ostateczne decyzje wyborców, co potwierdza hipotezę pierwszą.

Tabela 7

Agenda medialna i publiczna [\%]

\begin{tabular}{||l|c|c||}
\hline \multicolumn{1}{|c|}{ Nazwa Podmiotu } & Agenda medialna & Agenda publiczna \\
\hline Platforma Obywatelska & 40,0 & 32,13 \\
\hline Prawo i Sprawiedliwość & 39,0 & 31,78 \\
\hline Europa Plus Twój Ruch & 20,0 & 3,57 \\
\hline SLD-UP & 25,0 & 9,44 \\
\hline Polskie Stronnictwo Ludowe & 14,5 & 6,80 \\
\hline NP-JKM & 11,0 & 7,15 \\
\hline Solidarna Polska Z. Ziobro & 13,0 & 3,98 \\
\hline Polska Razem J. Gowina & 12,0 & 3,16 \\
\hline Ruch Narodowy & 6,0 & 1,39 \\
\hline Współczynnik Pearsona: 0,93 & \\
\hline
\end{tabular}

Źródło: Opracowanie własne.

Rezultaty badań potwierdzają również dwie kolejne hipotezy. Kampania wyborcza była prezentowana przez oba dzienniki przede wszystkim 
przez pryzmat działalności (w tym wizerunku, wypowiedzi) liderów list wyborczych i/lub często niekandydujących przywódców poszczególnych ugrupowań politycznych. Jedyną szansą na zaistnienie na łamach analizowanych dzienników kandydatów z dalszych miejsc na listach wyborczych były rozpowszechnianie przez nich kontrowersyjne postulaty programowe i/lub niestandardowe, najczęściej wpisujące się w kanony kampanii negatywnej działania promocyjne. Zarówno na łamach „Gazety Wyborczej”, jak i „Rzeczpospolitej” czytelnik mógł odnaleźć wybrane propozycje programowe poszczególnych ugrupowań politycznych - sposobem na zachowanie neutralności politycznej były podjęte przez oba dzienniki próby przedstawienia i graficznego zestawienia ze sobą stanowisk ugrupowań ${ }^{11}$ (zwizualizowanych nie tylko logiem, ale i wizerunkiem przywódcy) w różnych kwestiach związanych z polityką Unii Europejskiej w formie ankiety/kwestionariusza.

\section{Bibliografia}

Adamaszek K., Reszka P. P. (2014), Sztukmistrz z Lublina, „Gazeta Wyborcza” z dnia 12.05.2014 r.

Adamik-Szysiak M. (2014), Kampanie profrekwencyjne a postawy Polaków w kontekśsie wyborów do Parlamentu Europejskiego, „Środkowoeuropejskie Studia Polityczne", nr 1.

AJ, AGN (2014), Eurokoncert życzeń PiS, „Gazeta Wyborcza” z dnia 2.05.2014 r.

Badora B. (2014), CBOS, Wybory do Parlamentu Europejskiego, nr 40/2014, http:// www.cbos.pl/SPISKOM.POL/2014/K_040_14.PDF, 20.05.2015.

Bielecki T., Grochal R., Kondzińska A. (2014), Nasz euroranking, „Gazeta Wyborcza" z dnia 21.05.2014 r.

Bochniarz H. (2014), Eurowybory. Gra o przyszłość, „Gazeta Wyborcza” z dnia 20.03.2014 r.

Cybulska A. (2014), CBOS, Wybory do Parlamentu Europejskiego, nr 71/2014, http:// www.cbos.pl/SPISKOM.POL/2014/K_071_14.PDF, 20.05.2015.

Grochal R. (2014a), Kwaśniewski. Nie pojechałbym dziś do Moskwy, „Gazeta Wyborcza" z dnia 14.05.2014 r.

Grochal R. (2014b), Lewandowski. Imperialne erzace Putina, „Gazeta Wyborcza” $\mathrm{z}$ dnia 2.04.2014 r.

Grochal R. (2014c), Drużyna Tuska na eurowybory, „Gazeta Wyborcza” z dnia 7.03.2014 r.

${ }^{11}$ Oba dzienniki pomijały w ankietach najmniejsze ugrupowania, tj. Demokrację Bezpośrednią, Samoobronę i Partię Zielonych. 
Grochal R., Kondzińska A. (2014), Europa PO, Europa PiS, „Gazeta Wyborcza” $\mathrm{z}$ dnia 24.03.2014 r.

Kędracki J. (2014), Kim jest Adam Jarubas. Od radnego do marszatka, zawsze z PSL, „Gazeta Wyborcza” z dnia 2.04.2014 r.

Kondzińska A. (2014a), Radykalny radykał narodowy. Kim jest Łukasz Kluska. Radykalny radykat narodowy, „Gazeta Wyborcza” z dnia 14.05.2014 r.

Kondzińska A. (2014b), Schizofrenia narodowców, „Gazeta Wyborcza” z dnia 2.05.2014 r.

Kondzińska A. (2014c), Europejska drużyna Jarosława Kaczyńskiego, „Gazeta Wyborcza" z dnia 20.03.2014 r.

Majewski P. (2014a), Kto narzuci temat na finat kampanii, „Rzeczpospolita”z dnia 6.05.2014 r.

Majewski P. (2014b), W Europie jest szansa na egzotyczne koalicje, „Rzeczpospolita” $\mathrm{z}$ dnia $3.04 .2014 \mathrm{r}$.

Majewski P. (2014c), Na co pozwolić UE w sprawach sumienia, „Rzeczpospolita” $\mathrm{z}$ dnia 22.05.2014 r.

Majewski P. (2014d), Do euro spieszy się tylko lewicy, „Rzeczpospolita”z dnia 23.05.2014 r.

Majewski P. (2014e), Unia Europejska oczami kandydatów, „Rzeczpospolita” z dnia 14.04.2014 r.

Majewski P. (2014f), Starcie spin doktorów, „Rzeczpospolita” z dnia 17.05.2014 r.

Majewski P., Pieńkowski M. (2014), Psycholog za kulisami. Partie ukrywaja wsparcie ekspertów, „Rzeczpospolita” z dnia 14.05.2014 r.

Majewski P., Szułdrzyński M. (2014), Odłaczyć Rosję od kroplówki. Jarosław Kaczyński, ,Rzeczpospolita” z dnia 24.03.2014 r.

Mazurek R. (2014), Ja mówię prawdę. Reszta betkocze. Janusz Korwin-Mikke, lider Kongresu Nowej Prawicy, ,Rzeczpospolita” z dnia 22.03.2014 r.

McCombs M. (2008), Ustanawianie agendy. Media masowe $i$ opinia publiczna, Wydawnictwo Uniwersytetu Jagiellońskiego, Kraków.

Nizinkiewicz J. (2014a), Do eurolandu się nie spieszymy. Jacek Rostowski, „Rzeczpospolita" z dnia 6.05.2014 r.

Nizinkiewicz J. (2014b), Polsce nie trzeba euro, a Ukrainie Balcerowicza. Joachim Brudziński, „Rzeczpospolita” z dnia 10.03.2014 r.

Nizinkiewicz J. (2014c), Na prawicy czas na postpisowski AWS. Jacek Kurski, „Rzeczpospolita” z dnia 23.05.2014 r.

Nizinkiewicz J. (2014d), Korwin-Mikke jest rewersem Tuska. Pawet Kowal, „Rzeczpospolita" z dnia 23.05.2014 r.

Nizinkiewicz J. (2014e), Po Kaczyńskim PiS się rozjedzie. Michał Kamiński, „,Rzeczpospolita" z dnia 20.05.2014 r.

Nowakowska A. (2014a), To, co robi PiS, jest dobre dla Polski, ale nie dla PiS. Rozmowa z Michałem Kamińskim, „Gazeta Wyborcza” z dnia 8.03.2014 r. 
Nowakowska A. (2014b), Wędzona kietbasa wyborcza Kaczyńskiego, „Gazeta Wyborcza" z dnia 15.05.2014 r.

Olczyk E. (2014a), Odrażajacy, brudni, źli, czyli co wynika z wyborczych spotów, „Rzeczpospolita” z dnia 10.04.2014 r.

Olczyk E. (2014b), Kampania europejska od A do Z, „Rzeczpospolita” z dnia 21.05.2014 r.

Olczyk E. (2014c), Przedwyborcze pomysty, ,Rzeczpospolita” z dnia 22.05.2014 r.

Olczyk E. (2014d), Wybory jak festiwal obciachu, „Rzeczpospolita” z dnia 14.05.2014 r.

Olczyk E. (2014e), Pyskówki czas zaczać, „Rzeczpospolita” z dnia 19.03.2014 r.

Olczyk E., Grabek A. (2014), Po co ministrowi Europa, „Rzeczpospolita” z dnia 29.03.2014 r.

Olczyk E., Majewski P., Pieńkowski M. (2014), Ostatni atak na rywali, „Rzeczpospolita" $\mathrm{z}$ dnia 23.05.2014 r.

Pankowski K. (2014), CBOS, Wybory do Parlamentu Europejskiego, nr 56/2014, http://www.cbos.pl/SPISKOM.POL/2014/K_056_14.PDF, 20.05.2015.

PKW (2015), Wybory Prezydenta Rzeczypospolitej Polskiej 2015, http://prezydent2015.pkw.gov.pl/319_Pierwsze_glosowanie, 20.05.2015.

PKW (2014a), Wybory do Parlamentu Europejskiego, http://pkw.gov.pl/316_Wybory_do_Parlamentu_Europejskiego, 20.05.2015.

PKW (2014b), Wybory do Parlamentu Europejskiego zarzqdzone na dzień 25 maja 2014 r., http://pe2014.pkw.gov.pl/pl/, 20.05.2015.

Postanowienie Prezydenta Rzeczypospolitej Polskiej z dnia 19 lutego 2014 r. w sprawie zarzadzenia wyborów posłów do Parlamentu Europejskiego, Dz. U. 2014, poz. 231.

RED (2014), Kwestionariusz eurowyborczy, „Gazeta Wyborcza” z dnia 20.05.2014 r.

Roguska B. (2014), CBOS, 10 lat członkostwa Polski w Unii Europejskiej, nr 52/2014, http://www.cbos.pl/SPISKOM.POL/2014/K_052_14.PDF, 20.05.2015.

Słojewska A. (2014), Polska czołówka w Brukseli, „Rzeczpospolita” z dnia 22.04.2014 r.

Stankiewicz A. (2014), Rewolucja dojrzatych dzieci. Ryszard Kalisz, „Rzeczpospolita" z dnia 12.03.2014 r.

Strona internetowa Janusza Korwina-Mikke (2014), www.korwin-mikke.pl, 25.05.2014.

Wielowieyska D., Kursa M., Szaro G. (2014), Kampania na granicach, „Gazeta Wyborcza" z dnia 7.04.2014 r.

Wroński P. (2014), Pojedynki pewniaków i partyjnych czarnych koni, „Gazeta Wyborcza" z dnia 21.05.2014 r.

ZKDP - Związek Kontroli Dystrybucji Prasy (2014), Komunikat Zarzadu ZKDP o wysokości nakładów $i$ dystrybucji tytułów kontrolowanych przez ZKDP w 2014 roku, http://www.zkdp.pl/images/komunikat_2014.pdf, 20.05.2015. 


\title{
The elections to the European Parliament in 2014 in the nationwide dailies
} - a case study of "Gazeta Wyborcza" and "Rzeczpospolita"

\begin{abstract}
Summary
The article presents the results of research on the media agenda of two national dailies "Gazeta Wyborcza" and "Rzeczpospolita", related to popularizing the election campaign preceding the 2014 elections to the European Parliament. The subject of empirical research concerned both the presence of the issues concerning individual political groups, and their presentation to the public on the pages of each daily respectively. One of the results of the analysis is the confirmation of the hypothesis that there was a high degree of interdependence between the ranking of subjects presented by the media and the public agenda in the studied period (Pearson's coefficient amounted to 0.93$)$.
\end{abstract}

Key words: election campaign, the European Parliament, "Gazeta Wyborcza," "Rzeczpospolita," content analysis 